\title{
Consideration of the Communication Required of Doctors to Build a Strong Trusting Relationship with Patients and Primary Caregivers:
}

Matching of Doctors, Patients and Primary Caregivers

\section{患者・主介護者との強固な信頼関係構築のために 医師に求められるコミュニケーションの考察}

\section{一 医師，患者・主介護者のマッチングー}

\author{
Yumi Iwasaki *1, Yoshinobu Sato *2 \\ 医療法人双樹会 よしき往診クリニック 経営企画・広報部長 \\ 岩嵪 有美 \\ 関西学院大学専門職大学院 経営戦略研究科 教授

\section{佐藤 善信}

\footnotetext{
${ }^{* 1}$ Marketing Manager/Yoshiki Home Care Clinic, bjg0178@gmail.com

${ }^{* 2}$ Professor/Institute of Business and Accounting, Professional Graduate School, Kwansei Gakuin University, yoshisato@kwansei.ac.jp
}

\begin{abstract}
Home medical care is medical care that supports the lives of patients, and it requires a trust between the patients and their primary caregivers. However, communication between doctors and patients is not emphasized in the curriculum of Japanese medical schools. Thus, in clinical practice, many doctors face the problems of communication with patients and primary caregivers. In this study, we focused on "social style theory" (Merrill \& Reid, 1999), and clarified the communication skills required of the doctors for patients and primary caregivers to be able to recognize that they want this doctor to continue to take care of them until the end of the patient's life. As a result of the analysis, it became clear that in order for doctors to gain strong trust from the patients and primary caregivers, the doctors need to firstly construct a pyramid consisting of (1) medical technology, (2) medical thinking, and (3) human communication. The doctors also need (4) a social style matching the patient and primary caregivers, which affects the whole pyramid. Among them, the combination of drivers between doctor and patient (primary caregivers) should be especially noted in the "social style matching". Since drivers try to take control of each other's conversation, there is a high possibility that halation will occur. Doctors need "versatility" which allows them to consciously meet the social style needs of patients and primary caregivers.
\end{abstract}

Keyword : Medical education for doctors, Services marketing, Medical management, Home medical care, Social style theory

要約 : 在宅医療は患者の人生を支える医療であり, 医師に対する患者·主介護者の信頼は不可欠である。しかし, 我が国の医学 部教育では医師と患者との間のコミュニケーションは重視されておらず, 臨床の場で初めて, 患者·主介護者とのコミュニケー ションの課題に直面する医師は多い。本研究では“ソーシャルスタイル理論” (Merrill \& Reid, 1999) に着目し, 患者·主介護者 が「この医師に最期まで診てほしい」と認識するために必要な医師のコミュニケーション要件を明らかにした。分析の結果，医 師が患者·主介護者から強固な信頼を得るには，（1）診療技術，（2）診療思考，（3）ヒューマンコミュニケーションのピラミッ ドの構築が必要であり，全体に対して（4）ソーシャルスタイルのマッチングという条件が影響することが明らかになった。中 でも，医師と患者（主介護者）の関係における「ソーシャルスタイルのマッチング」で特に気を付けるべきは，ドライバ一同士 の組合せである。ドライバ一同士は互いに会話の主導権を握ろうとするため, ハレーションが生じる可能性が高い。医師には, 意識的に患者·主介護者のソーシャルスタイルの二ーズに合わせて対応する「バーサティリティ」能力が必要とされるのである。 キーワード : 医師の教育, サービスマーケティング, 医療経営, 在宅医療, ソーシャルスタイル理論

Information : Received 12 August 2019; Accepted 17 November 2019 


\section{I. テーマ選定の背景}

在宅医療とは医療従事者が患家を定期的に訪問して療 養管理を行うことであり，保険診療が適用される。1 回 の診察にかける時間は 10〜20 分と外来診療に比べると 長く，さらに，患者の生活スペースである自宅で診療を 行うため, 上り密なコミュニケーションが求められる。

日本の人口は 2010 年をピークに減少しており, 将来 的に医療機関は過利となり，競争が激化すると考元られ る。そのため,「患者に選ばれ続ける医療機関づくり」が 今後の課題になるであろう。

国はこれまで「かかりつけ医」の普及を推進してきた。 しかし，日本医師会の調査によると，「かかりつけ医がい る」と答えた者の割合は 53.7\% (Japan Medical Association Research Institute, 2015）と，患者の医療機関が固定され ていない状況が見られる。その要因として，日本の医療 制度の特徵である「国民皆保険」と「フリーアクセス」 があげられる。国民皆保険とは，全ての国民が公的医療 保険制度に加入し, 保険証 1 枚で一定の自己負担により 必要な医療サービスを受けることができる仕組みのこと を指す。またフリーアクセスとは，患者が受診する医療 機関を自由に選べ, 診療所から大学病院, 専門病院まで, 患者自身が望めばどこでも診てもらえる環境のことであ る (Ministry of Health, Labour and Welfare, 2011)。このよ うに，日本国民には多くの医療機関の選択肢が与えられ ている。この環境下で自院が患者に選ばれ続ける医療機 関となるには，医師は患者・主介護者との間に強固な信 頼関倸を築かなければならない。

自院（Y 診療所）は京都市にある在宅療養支援診療所 で, 2019 年 8 月 11 日時点で計 16 名の医師が所属してい る。患者の約 8 割が要介護者であり, 患者だけでなく, 主介護者とも医師のコミュニケーションが発生すること が多い。Y 診療所は開院以来，順調に患者数が推移して いる。しかし，「医師が気に入らない」という理由で患者 が $\mathrm{Y}$ 診療所から別の医院に移ったケースがいくつか見ら れた。在宅患者には訪問看護師やケアマネジャーといっ た他事業所の多職種職員が介入していることが多く，患 者や主介護者の医師に対する不満は地域に広がる恐れが
ある。 $\mathrm{Y}$ 診療所の診療において，具体的に下記のような コミュニケーションの問題が生じた。

例えば，患者・主介護者からの医師に対するクレーム として次の 3 つが典型例である。「患者に向かって仁王 立ちで喋るなんて偉そうだ。医師を変更してほしい。」「医 師は話ばかりして何をしに来たのか。なぜ聴診器も当て てくれないのか。」あるいは「何を根拠に胃癌だと判断し たのか。検查画像を元にした説明がないと納得できない じゃないか。がそうである。

また，患者，主介護者，医師の三者間での意思疎通の

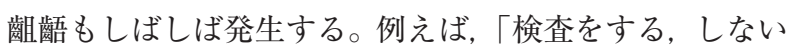
を巡って患者（妻）と主介護者（夫）の意見が食い違い， 夫婦喧㗆が勃発。巻き込まれた医師が主介護者を叱りつ けたため, 口論がさらに炎上し，収拾がつかなくなった。」 「医師の話そっちのけで，主介護者が患者に『ああしなさ い』『こうしなさい』と指示している。」腎疾患で療養管 理中の患者に皮膚疾患が生じたため, 総合内科医がフォ ローしようとしたところ，主介護者に『皮膚科に連れて 行くので，あなたには診てもらわなくてよい』と断られ た。がそうである。

ここで注目すべきは, 同じ医師でも患者が異なれば絶 大な信頼を得ており，「先生に看取りまでお願いしたい」 と言う患者もいることである。また医師を変えたところ， 新しい担当医師に心を開いた患者・主介護者がいる。そ れから，医師が患者への接し方を改めたところ，信頼を 寄せ始めた患者もいる。この現象に共通する要因は何で あろうか。そこで以下では, 患者・主介護者の信頼を得 るために, 特に医師に必要なコミュニケーション要件を 明らかにする。

在宅医療は慢性疾患や末期がんの患者が対象であり， 医師は「看取り」までを行う。治す医療ではなく、いわ ば，患者の人生を支える医療であり，患者・主介護者の 医師に対する信頼が不可欠である。つまり，医師のコミュ ニケーション能力が最も重要となる医療である。

しかしながら，Y 診療所の医師に聴く限り, 大学の医 学部で患者とのコミュニケーションを指導する教育はな く，また，医局に扔ける医師の評価も「患者からの信頼 の厚さ」は重視されていないそうである。その結果, 臨 床の現場に出て初めて, 患者・主介護者とのコミュニケー 


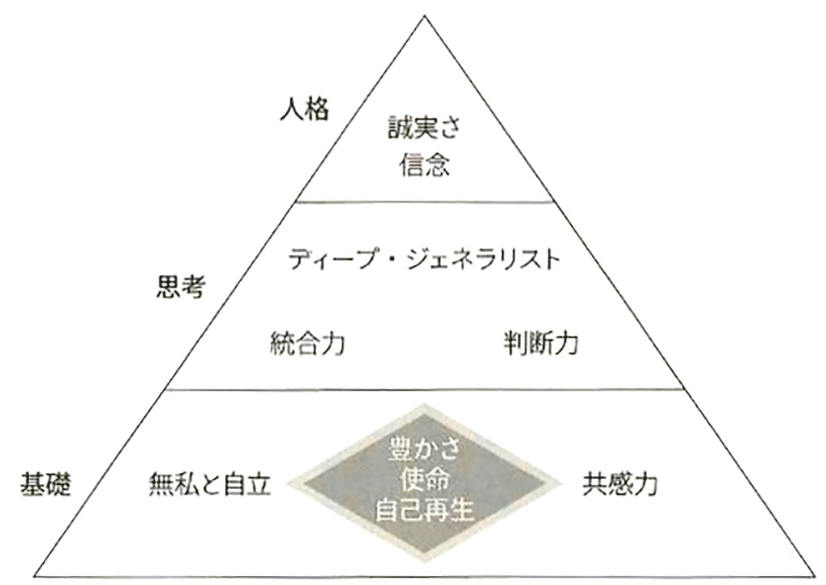

出所 : Sheth and Sobel (2000/2009, p. 325)

ションの課題に直面する医師が多い。

また，医療機関の経営者は，診療報酬やスムーズな診 療といった短期的利益を重視する傾向が強く，患者・主 介護者からの口コミ効果といった長期的利益が軽視され がちである。「コミュニケーションは診療報酬の点数に含 まれないから，頑張ってやるだけ無䭾だ」という見解を 述べる者もいる。彼らが理解していないのは，口コミに よるパブリックリレーションズの効果である。ロイヤル カスタマーのような患者・主介護者がいる医療機関は, ロコミの拡散により，地域に支持される医療機関になり 得る可能性が十分にある。

本研究では, 在宅医療における患者・主介護者と医師 間の強固な信頼関係の形成プロセスをコミュニケーショ ンの観点から明らかにし，今後の医療サービスの品質向 上に資することを目的としている。以下，本稿において 「強固な信頼」とは，患者・主介護者が「その医師に最期 まで診てほしい」と認識することと定義する。次に，第 II 節では先行研究について概観する。その後, 第 III 節に おいてはリサーチクエスチョンと調査方法が説明され る。第 IV 節は，分析結果を示す。最後の第 V 節におい ては, 本研究の結論と今後の研究課題が説明される。

\section{II. 先行研究}

本研究者は多くの文献を探索したが，医師と患者のコ ミュニケーションに関する先行研究は見つからなかった。 そこで，(1）医師と患者の信頼関係，（2）専門職（プロ フェッショナル）のあり方，（3）一般的な対人コミュニ ケーションをテーマにした先行研究を基に，本研究を進 めることにした。

Nishigaki, Asai, Ohnishi, and Fukui（2004）は，医師に 対する患者の信頼と不信の要因を分析している。この研 究では, 患者の医師に対する信頼関係構築には, 医師の 医学的な能力と，患者を一人の人間として尊重し真摰に 向き合おうとする医師の姿勢とを切り離すことは難しく, 医師に対する患者の感情的側面が重要な要因であること が明らかになっている。

Sheth and Sobel（2000/2009）の研究は, 「選ばれる専 門職（プロフェッショナル）に必要な要素」について次 のように説明する。優れたプロフェッショナルは 7 つ 核となる特質を身につけ，それらを統合している。彼ら はその上で行動すべてに豊かさ, 使命, 自己再生の精神 を吹き込む。これにより，専門職はクライアントとの幅 広い持続的な関係を生み出せるようになる（図 1）。

本研究者はこの 7 つ核となる優れた特質を医師に置 
き換え, 以下のように解釈した。(1)「無私と自立」, 患者 や主介護者, 雇用先に対し, 献身的でありながらも依存 しない。(2)「共感力」, 患者や主介護者の隠れたサインに 気づく。(3)「ディープ・ジェネラリスト」, 専門科領域以 外にも広く深い知識を身につけている。(4)「統合力」, 全 体を見渡す大局的な視野を持っている。(5)「判断力」, 患 者や主介護者に対して健全な意思決定ができる。6 「信 念」, 自分の価值観を知り, 強く信じている。(7)「誠実 さ」, 患者や主介護者から自分たちの期待に応えてくれる と信じられている。

本稿で中心となる先行研究は, アメリカの産業心理学 者 Merrill が 1968 年に提唱したソーシャルスタイル理論 である。それによると，対人行動において人間のコミュ ニケーションタイプは 4 つのスタイルに分類される。同 属のスタイルは相性が良いとされ, 異なるスタイルであっ ても，相手のスタイルを知り，コミュニケーションを工 夫することで対人スキルが増すとされる (Bolton \& Bolton, 1984; Merrill \& Reid, 1999)。

それぞれのスタイルのキーワードは次のようになって いる。まず，アナリティカルは「論理的」「几帳面」「神 経質」「規則正しい」「用心深い」。次に，エイミアブルは 「協力的」「サポート」「お世辞上手」「忍耐強い」「忠誠心 がある」。そして，エクスプレッシブは「社交的」「熱狂
的」「説得上手」「楽しいこと好き」「自発的」。最後に， ドライバーは「依存しない」「率直」「決断力がある」「実 用的」「効率的」である。

これらの性質を基に, 患者, もしくは主介護者のソー シャルスタイル別の特徴を仮説的に整理した（図 2）。

同様に, 医師のソーシャルスタイル別の特徵も仮説的 に整理した（図 3）。

\section{III. リサーチクエスチョンと調査方法}

先行研究からは, 患者・主介護者との信頼関係構築に おいて, 医師としての医学的能力はもちろん, 医師に対 する患者の感情的側面も重要であることが仮説的に明ら かになった。しかし，医師と患者のコミュニケーション について示唆する研究はなかった。そこで，本研究では ソーシャルスタイル理論に着目し，患者・主介護者から 「この医師に最期まで診てほしい」と思われるようになる ために，医師に必要なコミュニケーション要件を明らか にする。具体的には，（図 2）と（図 3）の仮説を検証す ることになる。

調査の目的は, 患者・主介護者のソーシャルスタイル 別に, 医師に求めるコミュニケーションの特徵を明らか

\begin{tabular}{|c|c|}
\hline アナリティカル & ドライバー \\
\hline $\begin{array}{l}\text { 診断背景や処方意図を詳しく知りたがる } \\
\text { 時間にうるさい } \\
\text { バイタルデータなど状態をこまめに管理 } \\
\text { 少しの状態変化に不安になる } \\
\text { 不安要素は医師に質問して解消したい } \\
\text { 検植結果など確信できる情報がないと } \\
\text { 行動に移せないい } \\
\text { 処置の順番や服薬指示を忠実に守る }\end{array}$ & 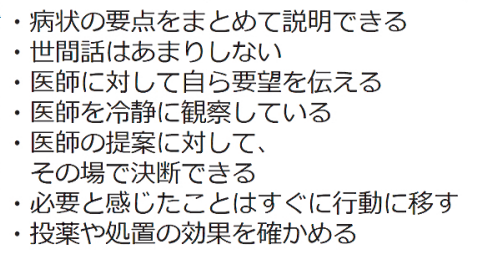 \\
\hline 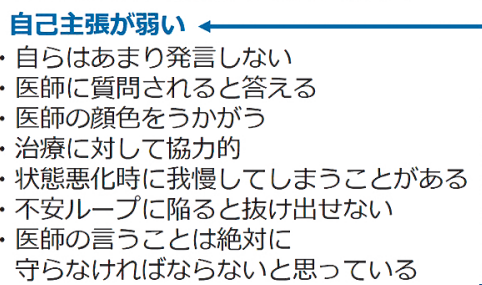 & 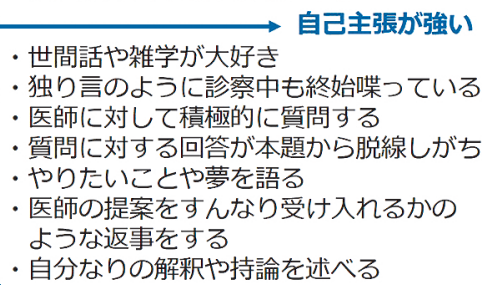 \\
\hline & \\
\hline
\end{tabular}




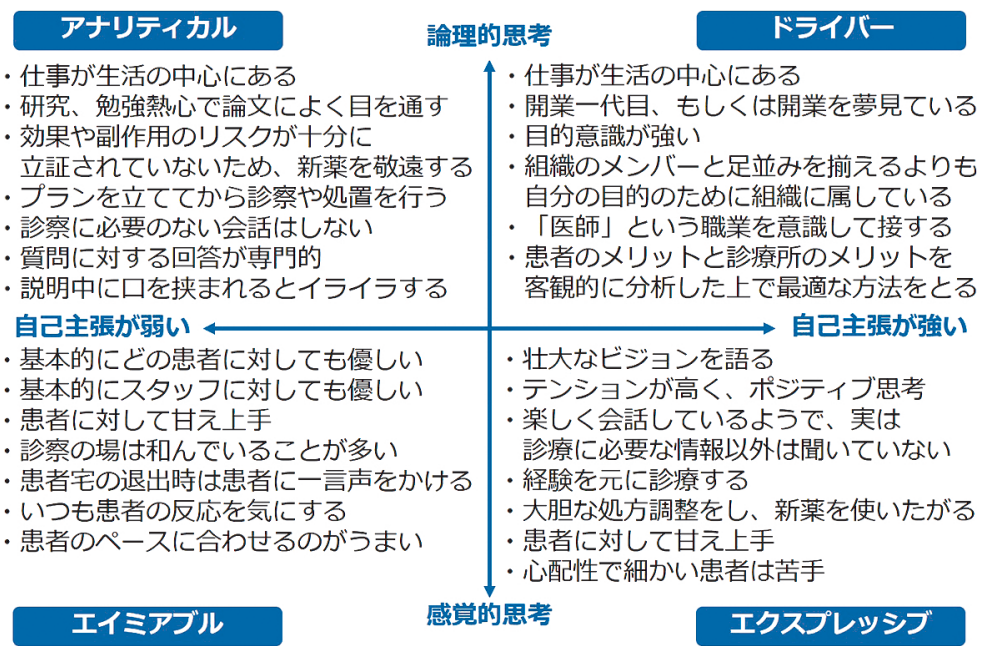

にすることである。調査対象者は，Y 診療所の訪問診療 を受けており，医師と強固な信頼関係が構築されている 患者がいる世帯の中から，ランダムに抽出した 15 世帯 20 名の患者と主介護者である。患者本人が独居，もしく は日常生活動作（ADL）が自立しており介護者不在の場 合は患者のみに，疾患や $\mathrm{ADL}$ 低下のために患者が回答 困難な場合は主介護者のみに調査を行った。なお，患者 と主介護者のソーシャルスタイルのタイプ別の判断は, 彼らのコミュニケーションスタイルを本研究者が注意深 く観察することによって判断した。

調査への参加については, 調査対象者の調查への中止 や離脱を保障し，調査への参加が自由な意思によること の理解を得た上で同意書に署名いただいた。

調査場所は京都市内にあるそれぞれの患者宅である。

調査は, 2018 年 11 月 9 日から 2018 年 12 月 22 日にか けて行った。

調査方法としては，次の 3 つの設問を中心にデプスイ ンタビューを行った。(1)通院歴と印象に残っている医師 とその理由。(2) Y 診療所で印象に残っている医師とその 理由。(3)信頼できる医師とその理由。また信頼できると 確信したタイミングはいつか，そのきっかけは何か。

各設問の目的を説明する。(1)信頼する医師と信頼関係 構築が困難な医師を明らかにし，特徵を探る。さらに，
患者（主介護者）の医師という職業に対する価値観を明 らかにする。(2Y 診療所における信頼する医師と信頼関 係構築が困難な医師を明らかにし, 特徵を探る。さらに, 患者（主介護者）の医師という職業に対する価値観を明 らかにする。(3医師に対する患者（主介護者）の信頼形 成の要因を明らかにする。

調査はその都度, 発言内容の検討と分析を行った上 で，次の調査を計画する過程を繰り返すグラウンデッド セオリーアプローチ（Strauss \& Corbin, 1991）の手法を とった。

また，本研究は $\mathrm{Y}$ 診療所院長の承認を得て行われた。

\section{IV. 分析結果}

本研究においては, 調査結果デー夕を次の手順で分析 した。(1)患者（主介護者）と, 彼らが信頼する医師, 信 頼関係構築困難な医師のソーシャルスタイルをマッピン グした。(2)患者（主介護者）のソーシャルスタイル別に インタビュー結果を列挙した。(3)患者（主介護者）のソー シャルスタイルに関係なく共通する, 医師に求めるコミュ ニケーション要素を抽出した。(4)患者 (主介護者)のソー シャルスタイル別に医師という職業に対する価値観の違 
いを明らかにした。(5)患者（主介護者）のソーシャルス タイル別に共通する医師に求めるコミュニケーション要 素を抽出した。

そして，回答者である患者（主介護者）と，彼らが信 頼する医師，信頼関係構築困難な医師のソーシャルス夕 イルを（表1）にまとめた。ソーシャルスタイル別の患 者（主介護者）数に対する，それぞれの項目に該当する 医師のソーシャルスタイル別人数の比率を計算し, 0.50 より大きい数值に色付けした。なお，「信頼する医師 $1 」$ 「信頼する医師 $2 」$ とに，彼らが最期まで診てもらい たいと思っている医師に変わりはないが,「医師 $2 」 に$ 比べて「医師 $1 」$ の方が患者（主介護者）からの信頼が 厚い。

\section{V. 結論と今後の研究課題}

医師と患者（主介護者）のソーシャルスタイルの特徵 は，調査によってすべて検証された。また，医師が患者・ 主介護者からの信頼を得るには，(1）診療技術，（2）診 療思考，（3）ヒューマンコミュニケーションのピラミッ ドの構築が必要であり,ささに，全体に対して (4) ソー シャルスタイルのマッチングが影響する（図 4）。以下 で，図 4 を説明する。
診療技術の代表は「医療技術」である。つまり，医師 に在宅医療に必要な診察や医療処置，処方調整ができる 技術が備わっていることである。

次に, 診療思考について説明する。第 1 に「信念」で あるが，これは医師が自身の価值観を知り，深く信じて いることである。第 2 は「誠意」である。医師が患者と 主介護者に対して献身的であり，彼らから期待に応えて くれると信じられていることである。第 3 は,「将来を 見据えた診療方針」であり，これは，医師が患者の状態 悪化時だけでなく, 患者の今後の人生を鑑みて診療方針 を考えられることである。

それから，ヒューマンコミュニケーションについて説 明する。表 1 より, ソーシャルスタイルの相性が良くな かったとしても, 患者（主介護者）と強い信頼関係を築 く医師の存在が明らかになった。彼らには「バーサティ リティ」の高さがうかがえる。バーサティリティとは, 意識的に患者・主介護者のソーシャルスタイルのニーズ （図 5）（図 6）に合わせてコミュニケーションを調整す る医師の能力である。

（1）診療技術，（2）診療思考，（3）ヒューマンコ ミュニケーションの全体に作用する条件が「ソーシャル スタイルのマッチング」である。ここでは表 1 の組合せ の数值が 0.50 より大きいものに着目して, 以下で考察 する。

表 1 患者（主介護者）のソーシャルスタイルと彼らが信頼する医師, 信頼関係構築困難な医師のソーシャルスタイル

\begin{tabular}{|c|c|c|c|c|c|c|c|c|c|c|c|c|c|c|}
\hline \multicolumn{3}{|c|}{$\begin{array}{c}\text { ソーシャルスタイルの } \\
\text { マッチング }\end{array}$} & \multicolumn{4}{|c|}{ 信頼する医師 1} & \multicolumn{4}{|c|}{ 信頼する医師 2} & \multicolumn{4}{|c|}{ 信頼関係構築困難な医師 } \\
\hline \multirow{12}{*}{ 患者 } & \multirow{3}{*}{$\mathrm{AN}$} & & $\mathrm{AN}$ & $\mathrm{AI}$ & EX & $\mathrm{DR}$ & $\mathrm{AN}$ & $\mathrm{AI}$ & EX & DR & AN & $\mathrm{AI}$ & EX & DR \\
\hline & & 人数 & 3 & 0 & 1 & 0 & 2 & 0 & 2 & 0 & 0 & 0 & 0 & 3 \\
\hline & & 4 & 0.75 & 0.00 & 0.25 & 0.00 & 0.50 & 0.00 & 0.50 & 0.00 & 0.00 & 0.00 & 0.00 & 0.75 \\
\hline & \multirow{3}{*}{ AI } & & $\mathrm{AN}$ & $\mathrm{AI}$ & EX & DR & AN & $\mathrm{AI}$ & EX & DR & $\mathrm{AN}$ & $\mathrm{AI}$ & EX & DR \\
\hline & & 人数 & 1 & 1 & 3 & 1 & 1 & 0 & 1 & 1 & 0 & 0 & 0 & 0 \\
\hline & & 6 & 0.17 & 0.17 & 0.50 & 0.17 & 0.17 & 0.00 & 0.17 & 0.17 & 0.00 & 0.00 & 0.00 & 0.00 \\
\hline & \multirow{3}{*}{$\mathrm{EX}$} & & $\mathrm{AN}$ & $\mathrm{AI}$ & EX & DR & $\mathrm{AN}$ & $\mathrm{AI}$ & EX & DR & AN & $\mathrm{AI}$ & EX & DR \\
\hline & & 人数 & 0 & 0 & 3 & 1 & 1 & 1 & 1 & 1 & 4 & 0 & 0 & 0 \\
\hline & & 4 & 0.00 & 0.00 & 0.75 & 0.25 & 0.25 & 0.25 & 0.25 & 0.25 & 1.00 & 0.00 & 0.00 & 0.00 \\
\hline & \multirow{3}{*}{ DR } & & $\mathrm{AN}$ & $\mathrm{AI}$ & EX & DR & AN & $\mathrm{AI}$ & EX & DR & AN & $\mathrm{AI}$ & EX & DR \\
\hline & & 人数 & 0 & 0 & 4 & 1 & 1 & 0 & 1 & 0 & 0 & 0 & 0 & 4 \\
\hline & & 6 & 0.00 & 0.00 & 0.67 & 0.17 & 0.17 & 0.00 & 0.17 & 0.00 & 0.00 & 0.00 & 0.00 & 0.67 \\
\hline
\end{tabular}

(注) $\mathrm{AN} ：$ アナリティカル, $\mathrm{AI}$ ：エイミアブル， $\mathrm{EX}$ ：エクスプレッシブ, $\mathrm{DR}$ ：ドライバー 
ソーシャルスタイル理論 (Bolton \& Bolton, 1984; Merrill \& Reid, 1999）において，同属のスタイルは相性が良いと されるが，医師と患者（主介護者）の間においても，ア ナリティカル同士，エクスプレッシブ同士は相性が良い といえる。また図 5 で明らかになっているように, エイ ミアブルの患者（主介護者）は，医師という職業に信頼 の念を抱いているため, ソーシャルスタイルに関わらず に医師を信頼する傾向がある。
一方で，医師と患者（主介護者）の間において，ドラ イバー同士の組合せは相性が良いとはいえず，特に注意 が必要である。なぜならば, ドライバー同士は医師と患 者・主介護が互いに会話の主導権を握ろうとするため, ハレーションが生じる可能性が高いためである。今回の 調査では, ドライバーの患者 (主介護者) はエクスプレッ シブの医師との相性が良い傾向が見られたが，インタ ビューの中で, 彼らはエクスプレッシブの医師の医師ら

図 4

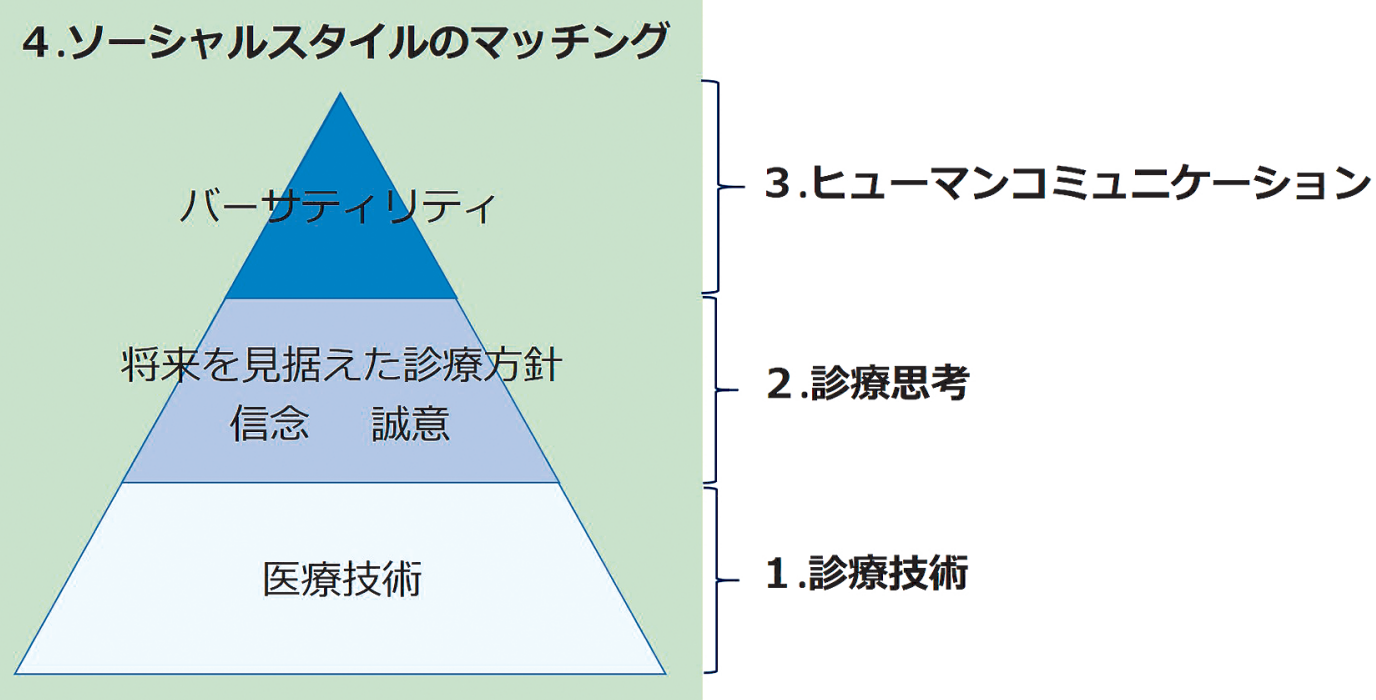

図 5 患者（主介護者）のソーシャルスタイル別, 医師という職業に対する価值観の違い

\begin{tabular}{|c|c|}
\hline \\
\hline \multicolumn{2}{|r|}{$\begin{array}{l}\text { 医師といえどもサービス業。 } \\
\text { あくまで患者が主体である。 } \\
\text { 患者に不快な思いをさせない } \\
\text { ように対応すべき。 }\end{array}$} \\
\hline $\begin{array}{l}\text { 己主張が弱い } \longleftarrow \text { 夝懸命勉強して医学部に行き、 } \\
\text { 国家試験に合格したのだから、 } \\
\text { 「医師」というだけで信頼できる。 } \\
\text { 患者は医師の言うことを守るべきだ。 }\end{array}$ & $\begin{array}{l}\longrightarrow \\
\text { 自己主張が強い } \\
\text { 「医師」の前に、人間力が大事。 } \\
\text { 同じ人間として肩書関係なく } \\
\text { 対等な関係を築きたい。 }\end{array}$ \\
\hline エイミアブル & エクスプレッシブ \\
\hline
\end{tabular}




\section{アナリティカル}

(1)医師の学歴と専門分野を教えてほしい 専門分野は患者の疾患とマッチングさせてほしい。 (3)患者(主介護者)の晢問に対して、丁䑶でわかりやすい説明をしてほしい。 (4)患者主介謢者からの依頼はスト゚ード感を持つて対応してほしい。 (5)患者(主介護者)が考えすぎて決断できないときは、医師が決めてほしい。 (6)医師は常に研究、勉強し、最新の專門知識を持方合わせてほしい。 (7)訪問日時は患者(主介護者)の都合に合わせてほしい。 7)訪問日時は患者(主介護者)の都合に合わせてほしい。 8)往診要請をしたとさはすぐに駆けつけてほしい。 9)身だしなみは清潔にしてほしい。 (2)計画的な治療を行い、その計画に至つた経緯を教えてほしい。

\section{論理的思考}

\section{ドライバー}

(1)医師としてのキャリアと総合診療のスキルを教えてほしい。 (2)診原経過を継続して把握してほしいので、

1人の医師と長い付き合いをしていきたい。

(3)主導権は患者(主介護者)が握りたいので、まず自分の訴えを聞いてほしい。

(4)患者(主介護者)の質問に対して、要点のみをはつきり伝えてほしい。

(5)患者(主介護者)の要望に対して、臨機応変に動いてほしい。

(6)医療知識が呆しく医療処置や処方はよくわからないが、

6)医療知識者主介護者)が最終決定したい。

患者(主介護者)が最終決定したい。
(7)訪問日時は患者(主介護者)の都合に合わせてほしい。

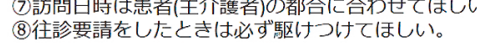

(8)往診要請をしたときは必ず駆け
(9)身だしなみは清潔にしてほしい。

\section{自己主張が弱い}

\section{自己主張が強い}

(1)患者(主介護者)と向き合つて目線を合わせてほしい。 (2)「医師」という職業に緊張してしまうので、優しく接してほしい。 3)会話に世間話を織り交ぜて、緊張を解いてほしい。 (4)どんなときも患者(主介護者)を支えてほしい。 (5)説明は上手ではないが、患者(主介護者)の話は辛抱強く聞いてほしい。 (6)患者(主介護者)からの質問は、ないがしろにせず答えてほしい。 (7)要望を上手に伝えられないため、

患者(主介護者)の思いをくみ取つて導く診療をしてほしい。 8)患者(主介護者が皆問しなくても、好方意図や診療計画を説明してほしい。 (9)蝟者(主介護者)が不安ループに陥つているときは 不安を払拭する言葉をかけてほしい。

\section{エイミアブル} 感賞的思考
(1)患者(主介護者)と向き合って目線を合わ甘てほいい。

(2)人として対等な姿勢で接してほしい。

(3)患者(主介護者)の世間話に付き合ってほしい。

(4)話を遮らずに、まず患者(主介護者)の訴えを聞いてほしい。

5)医療とは関係ないことも質問するが、

患者(主介護者)からの質問は嫌な顔せず答えてほしい。

(6)データだけではなく、診察時の患者本人の状態を診てほしい。

(7患者に合わせた診療計画を提案してほしい。

88患者(主介護者)からの要望がなくとも、医師が自主的に動いてほしい。

(9患者(主介護者)の疾患管理については、白黒はつきり指導してほしい。
しからぬユーモアな人間性を高く評価していた。

またソーシャルスタイル理論において対極の関係に あるエクスプレッシブの患者（主介護者）とアナリティ カルの医師の相性は良くない。診療の場では, エクスプ レッシブの患者（主介護者）が医師の話を聞かず，診療 とは関係のないことを多弁に語る態度に，アナリティカ ルの医師が計画通りに診療を進められないことに痺れを 切らし，高圧的になる場面が度々見受けられた。図 5 か らもわかるように，医師と対等な関係を築きたいと考え ているエクスプレッシブの患者（主介護者）は，医師が 高圧的になった時点で信頼に值しないと捉えるようで ある。

さらに, アナリティカルの患者（主介護者）とドライ バーの医師の組合せも良いとはいえないことがわかった。 アナリティカルの患者（主介護者）は不安が解消できな いと決断が下せない。それに対して，ドライバーの医師 は医師の権限を前面に打ち出し，次々と決断を下してい く。そこで，アナリティカルの患者（主介護者）にとっ ては,「あの先生は私のことを理解してくれない」と映っ てしまうのである。
本研究は, Y 診療所の 15 世帯 20 名の患者と主介護者 を対象にした調査に基づく結論である。結論の有効性を より確かなものにするために, 今後は以下の 2 つの課題 に取り組む必要がある。

第 1 の課題は, 調査対象者の拡大である。それはサン プル数の拡大ばかりではない。今後は, 調査対象者とし て，医師と初めて対面することになった患者（主介護者） が, どのようなプロセスを経て「その医師に最期まで診 てほしい」と認識するようになるのかについて, 本研究 の仮説を実証することが重要である。

今後の第 2 の研究課題は, 医師の患者（主介護者）用 のコミュニケーション・ハンドブックを制作し，それを 様々な診療所の医師に使用してもらい，検証を繰り返す アクションリサーチの必要性がある。

\section{References}

Bolton, R., \& Bolton, D. G. (1984). Social style/Management style (pp. 14-28). New York: American Management Association.

Japan Medical Association Research Institute. (2015). The 5th Nihon no iryo ni kansuru ishiki chousa: Japan Medical Association regular press conference. Japan Medical Association Research Institute Working Paper, January 28, 331, 
21. (日本医師会総合政策研究機構 (2015).「第 5 回日本の 医療に関する意識調査 日本医師会定例記者会見」『日医総 研ワーキングペーパー』1月 28 日，331，21.）(In Japanese) Merrill, D. W., \& Reid, R. H. (1999). Personal styles and effective performance. New York: CRC Press.

Ministry of Health, Labour and Welfare. (2011). Part 2, Chapter 4, Section 1, Kokumin kaihoken seido no kenji. Annual Health, Labour and Welfare Report 2010-2011 (p. 239). (厚生労働省 (2011).「第 2 部，第 4 章，第 1 節 国民皆保険制度の堅持」 『平成 23 年版厚生労働白書』p. 239) (In Japanese)

Nishigaki, E., Asai, A., Ohnishi, M., \& Fukui, T. (2004). Concepts of trust and distrust in physician: Patient relationship in Japan. Japanese Journal of Interpersonal and Social Psychology (Osaka University Knowledge Archive), 4, 11-20. (西垣悦代 · 浅井 篤・大西基喜・福井次矢 (2004)。「日本人の医療に対する 信頼と不信の構造 : 医師患者関係を中心に」『対人社会心理 学研究 (Osaka University Knowledge Archive)』4, 11-20) (In Japanese with English Abstract)

Sheth, J. N., \& Sobel, A. (2000). Clients for life. New York: Free Press: Simon \& Schuster.（羽物俊樹（訳）（2009）。『選ばれ るプロフェッショナル』英治出版)

Strauss, A., \& Corbin, J. (1991). Basics of qualitative research: Grounded theory procedures and techniques. Thousand Oaks, CA: Sage Publications. 